\title{
PERTANGGUNGJ AWABAN NEGARA TERKAIT PERMASALAHAN HUKUM YANG TIMBUL AKIBAT INSIDEN TERORISME MARITIM
}

\author{
Try Satria Indrawan Putra ${ }^{2 *}$, Lazarus Tri Setyawanta ${ }^{2}$ \\ 1Program Studi Magister IImu Hukum, Fakultas Hukum, Universitas Diponegoro \\ 2Fakultas Hukum, Universitas Diponegoro \\ satriaindrawantry@gmail.com
}

\begin{abstract}
One of the threats facing maritime security today is Maritime Terrorism. Various legal issues can cause disputes between countries related to maritime terrorism incidents, including those arising from the actions of coastal states and flag states. The method of approach used in this legal research is normative juridicial, which uses literature as the main data. The results of this study are that coastal state are considered responsible if there is negligence in maritime terrorism incidents in their territorial waters, while the flag state is also responsible if the ship is used for terrorist attacks on ships, ports, or maritime installations in other countries when the flag state is considered negligent in building proper control of the ship that will use its flag.
\end{abstract}

\section{Keywords: State Responsibility; Maritime Terrorism; Maritime Security.}

\begin{abstract}
ABSTRAK
Ancaman yang dihadapi keamanan maritim dewasa ini salah satunya adalah Maritime Terrorism atau Terorisme Maritim. Berbagai permasalahan hukum dapat menyebabkan perselisihan antarnegara terkait insiden terorisme maritim, termasuk yang timbul dari tindakan negara pantai, negara bendera kapal dan/ atau negara lain. Tujuan penelitian ini adalah untuk mengetahui bagaimana pertanggungjawaban negara terhadap permasalahan hukum yang timbul akibat dari insiden terorisme maritim baik bagi negara pantai maupun negara bendera kapal. Metode pendekatan yang digunakan dalam penelitian hukum ini adalah yuridis normatif, yaitu menggunakan bahan kepustakaan sebagai data utama. Hasil dari penelitian ini adalah Negara pantai dianggap bertanggungjawab apabila terdapat kelalaian dalam insiden terorisme maritim di wilayah perairannya, sedangkan negara bendera kapal juga bertanggung jawab jika kapalnya digunakan untuk serangan teroris terhadap kapal, pelabuhan, atau instalasi maritim negara lain ketika negara bendera dianggap lalai dalam membangun kontrol yang tepat atas kapal yang akan mengibarkan benderanya.
\end{abstract}

\section{Kata Kunci: Pertanggungjawaban Negara; Terorisme Maritim; Keamanan Maritim.}

\footnotetext{
${ }^{*}$ Corresponding Author
} 
Jurnal Pembangunan Hukum Indonesia

Volume 2, Nomor 1, Tahun 2020
Program Studi Magister Ilmu Hukum Fakultas Hukum Universitas Diponegoro

\section{A. PENDAHULUAN}

Keamanan maritim merupakan pilar penting perdamaian dan keamanan internasional, akan tetapi istilah keamanan maritim sendiri dapat diartikan dengan berbeda-beda. Seperti yang dinyatakan oleh Ban Ki-Moon:"Tidak ada defenisi yang diterima secara universal dari istilah 'keamanan maritim'. Beberapa penulis mengartikan "Keamanan, sebagai pekerjaan untuk melindungi orang-orang yang ingin melukai kita secara sengaja". Sementara penulis lain lebih tepat menggambarkannya sebagai "perlindungan tanah negara dan wilayah maritim, infrastrutktur, ekonomi, lingkungan, dan masyarakat dari tindakan berbahaya tertentu yang terjadi di laut.

Terlepas dari beberapa pengertian istilah tersebut, ancaman yang dihadapi keamanan maritim dewasa ini salah satunya adalah Maritime Terrorism atau Terorisme Maritim. Terorisme maritim pada kenyataannya adalah salah satu ancaman paling serius bagi perdamaian dan keamanan internasional, sebagaimana diakui dalam resolusi terbaru DK PBB. Ini membahayakan tujuan piagam PBB, yang mana bukan hanya sekadar memelihara perdamaian dan keamanan, akan tetapi juga ekonomi dunia, kebebasan laut, lingkungan laut yang utuh, dan kehidupan manusia.

Serangan teroris yang melibatkan kepentingan maritim tidak pernah terjadi sebelumnya. Sebagaimana yang terjadi pada insiden Achille Lauro 1985 adalah salah satu contoh pertama aktivitas teroris yang terjadi di laut. Akan tetapi, insideninsiden ini tidak mengarah pada kekhawatiran yang meluas tentang aset maritim yang menjadi sasaran kegiatan teroris sampai setelah serangan 11 September di AS (Garmon, 2002).

Serangan 11 September yang terjadi di Amerika Serikat, menegaskan dampak buruknya terorisme terhadap dunia. Serangan terhadap USS Cole pada tahun 2000, MV Limburg pada tahun 2002, SuperFerry 14 pada tahun 2004 dan M Star pada tahun 2010 dapat digolongkan sebagai tindakan 'Terorisme Maritim' sebuah pengingat yang tegas bahwa jalur pelayaran laut di dunia masih sangat rentan (Wee, 2017). Wilayah laut memiliki beberapa atribut yang pada dasarnya bisa sangat menguntungkan bagi kegiatan terorisme, (misalnya, kekebalan hukum dalam kaitannya dengan kegiatan di laut lepas dan upaya yang saling bertentangan oleh beberapa negara dalam mencoba menciptakan keamanan di wilayah pesisirnya dan fasilitas pelabuhan.

Memahami konsep terorisme maritim adalah sebuah hal yang problematis, apalagi untuk membedakannya dengan pembajakan, karena bajak laut berkolusi dengan teroris, dan teroris mengadopsi taktik bajak laut melakukan serangan terorisme maritime (Young, \& Valencia, 2003). Untuk membedakannya Young dan Valencia menitikberatkan pada latar belakang yang berbeda dari pembajakan dan terorisme maritim, yakni pembajak termotivasi oleh tujuan ekonomi, sedangkan teroris termotivasi oleh tujuan ideologi politk atau agama (Ho, 2006). 
Jurnal Pembangunan Hukum Indonesia

Volume 2, Nomor 1, Tahun 2020
Program Studi Magister Ilmu Hukum Fakultas Hukum Universitas Diponegoro
Kehadiran kelompok-kelompok terror seperti Jemaah Islamiyah (JI), Abu Sayyaf Group (ASG), Moro Islamic Liberation Front (MILF), merupakan ancaman nyata terhadap jalur perdagangan dunia. Strategi terorisme sendiri mengalami sebuah pergeseran target, yang awalnya adalah target-target fasilitas politik, diplomatik dan militer menjadi "softeconomic target", dimana target yang dituju adalah terget-target ekonomi.

Rezim hukum internasional telah berkembang dengan baik dalam menangani maslaah terorisme maritim. Namun, ada aspek-aspek tertentu dari hukum internasional yang masih menimbulkan beberapa perdebatan. Satu masalah khusus adalah terkait penerapan hukum mengenai pembajakan pada kasus terorisme maritim. Meskipun hukum pembajakan internasional tidak secara khusus berlaku dalam kasus terorisme maritim, hukum laut internasional akan berlaku dalam menentukan tanggung jawab negara pantai dan negara bendera kapal, serta tanggung jawab negara yang mengganggu hak navigasi dari kapal asing.

Pada tahun 1985, insiden penting Achille Lauro, yang dianggap sebagai kasus terorisme maritim yang paling terkenal di era modern, telah mendorong Organisasi Maritim Internasional (IMO) untuk menginisiasi pengaturan hukum internsaional terkait terorisme maritim (Balkin, 2006). Setelah insiden Achille Lauro, Majelis Umum PBB meminta IMO untuk mempelajari masalah terorsime di atas kapal atau terhadap kapal-kapal dengan maksud untuk membuat rekomendasi tentang langkah- langkah yang tepat. Pada bulan November 1986, Italia, Austria, dan Mesir menyerahkan kepada IMO sebuah rancangan Konvensi Internasional baru untuk Menekan terorisme maritim. Draft tersebut didasarkan pada tiga konvensi yang ada terkait dengan terorisme, termasuk Konvensi Den Haag tentang Pembajakan Pesawat, Konvensi Montreal tentang Sabotase Pesawat Udara, dan Konvensi Sandera. IMO pada pertemuan yang diadakan pada November 1986 dengan suara bulat memutuskan untuk mempertimbangkan menerbitkan dan membentuk Komite Persiapan Ad Hoc untuk merancang Konvensi. Setelah dua tahun negosiasi, IMO mengadopsi Konvensi Roma untuk Tindakan Melawan Hukum terhadap Keselamatan Navigasi (Konvensi SUA 1988) dan Protokol Roma untuk Tindakan Melanggar Hukum terhadap Keamanan di Landas Kontinen (SUA Fixed Paltforms Protocol 1988).

Konvensi SUA tidak mendefinisikan istilah 'terorisme' atau 'terorisme maritim'. Sebaliknya konvensi ini mengidentifikasi beberapa pelanggaran yang relevan atau tindakan melawan hukum (Treves, 1990). Pasal 3 Konvensi SUA mengklasifikasikan hal-hal berikut sebagai tindakan yang melanggar hukum:

a) Penyitaan atau pelaksanaan kontrol atas kapal dengan intimidasi

b) Kekerasan terhadap seseorang di atas kapal jika kekerasan berpotensi membahayakan keselatan navigasi kapal 
Jurnal Pembangunan Hukum Indonesia

Volume 2, Nomor 1, Tahun 2020
Program Studi Magister Ilmu Hukum Fakultas Hukum Universitas Diponegoro c) Penghancuran atau perusakan kapal atau muatannya

d) Menempatkan perangkat atau bahan untuk menghancurkan atau merusak kapal atau muatannya

e) Penghancuran, pengrusakan dan gangguan ke fasilitas navigasi

f) Membahayakan kapal dengan mengkomunikasikan informasi palsu.

Sesuai dengan Konvensi SUA, melukai atau membunuh siapa pun sehubungan dengan pelanggaran atau upaya percobaan dari salah satu pelanggaran yang disebutkan di atas juga merupakan pelanggaran. Konvensi juga membuat upaya mengancam dan bersekongkol dengan tindakan yang disebutkan diatas merupakan pelanggaran.

Konvensi SUA memberlakukan kewajiban pada Negara-negara pihak untuk menerapkan yurisdiksi pidanya terhadap penyitaan, kontrol, penghancuran dan perusakan kapal yang melanggar hukum di dalam dan di luar yurisdiksi territorial negara mereka, termasuk di perairan teritorialnya. Negara-negara pihak berkewajiban membuat pelanggaran ini dapat dihukum berdasarkan hukum nasionalnya, dengan mempertimbangkan dampak buruk dari pelanggaran-pelanggaran tersebut.

Konvensi SUA mengenalkan prinsip Aut Dedere Aut Judicare dimana para pihak dalam Konvensi SUA diwajibkan untuk menuntut pelaku atau mengekstradisi pelaku ke negara mereka dapat diadili. Konvensi SUA mulai berlaku pada 1 Maret
1992, akan tetapi beberapa negara sangat lambat dalam meratifikasi Konvensi SUA. Perlu disebutkan disini bahwa Indonesia dan Malaysia, dua Negara yang sangat penting bagi navigasi internasional ketika mereka berbatasan dengan Selat Malaka dan Singapura, bukan merupakan pihak pada Konvensi ini. Setiap tahun, lebih dari 50.000 kapal melewati Selat Malaka dan Singapura, membawa sepertiga dari perdagangan global. Selat Malaka adalah salah satu tempat paling rentan untuk serangan teroris (Unii, 2006).

Resolusi Dewan Keamanan 1373 telah memberlakukan kewajiban pada negara untuk tidak memberikan segala bentuk dukungan aktif atau pasif kepada entitas atau orang yang terlibat dalam aksi teroris, termasuk dengan menekan perekrutan anggota kelompok teroris dan menghilangkan pasokan senjata untuk teroris. Setiap pelanggaran atas kewajiban dan tanggung jawab ini dapat menimbulkan perselisihan antar negara, atau perselisihan antara negara dan aktor non-negara.

Berbagai permasalahan hukum dapat menyebabkan perselisihan antarnegara terkait insiden terorisme maritim, termasuk yang timbul dari tindakan negara pantai, negara bendera kapal dan/ atau negara lain. Sudah menjadi kewajiban negara pantai untuk memastikan keamanan navigasi bagi kapal asing. Pengiriman internasional yang modern sebagian besar merupakan system berbasis negara bendera. Hanya negara bendera yang memiliki otoritas penuh atas kapal yang mengibarkan benderanya. Yurisdiksi negara lain atas kapal-kapal 
Jurnal Pembangunan Hukum Indonesia

Volume 2, Nomor 1, Tahun 2020
Program Studi Magister Ilmu Hukum Fakultas Hukum Universitas Diponegoro ini sangat terbatas. Namun, tidak semua negara bendera serius dalam melaksanakan yurisdiksinya secara efektif dan mengontrol kapal yang mengibarkan benderanya. Fenomena yang dihasilkan dari pendaftaran terbuka Bendera Kemudahan (Flag of Convenience) berarti bahwa kewarganegaraan diberikan kepada entitas yang bukan warga negara, dan kepemilikannya seringkali tidak diketahui. Situasi ini meningkatkan kemungkinan terjadinya insiden terorisme maritim oleh kelompok teroris.

Kelompok-kelompok teroris yang beroperasi di laut telah lama diabaikan sebagai ancaman yang nyata terhadap keamanan maritim. Dampak nyata dari tindakan terorisme maritim tidak hanya dirasakan dalam skala lokal, nasional dan regional, akan tetapi sudah menjadi konsekuensi internasional. Solusi untuk permasalahan Terorisme Maritim ini sangat penting, karena "tidak ada satu negarapun yang memiliki kedaulatan, kapasitas, dan kendali atas aset, sumber daya, dan tempat dari ancaman kejahatan transnasional ini. Dengan demikian negara perlu bekerja sama untuk memungkinkan hukum internasional yang efektif untuk memerangi Terorisme Maritim.

Teori berfungsi memberikan argumentasi yang meyakinkan bahwa hal-hal yang dijelaskan adalah ilmiah karena pada dasarnya semua penelitian bersifat ilmiah maka dari itu harus berbekal teori. Teori-teori yang akan digunakan dalam penelitian ini antara lain:

a. Teori Yurisdiksi
Yurisdiksi berhubungan sangat erat dengan kedaulatan karena sering didefinisikan sebagai "kewenangan suatu negara untuk setiap saat ikut dalam perkembangan hukum internasional", di mana dalam dunia yang terdiri dari berbagai negara berdaulat, setiap negara dituntut untuk mengubah kedaulatannya dengan memberikan imperium yaitu mengadopsi hukum, serta untuk juris-dicere yaitu menetapkan hukum yang terkait dengan orang, aktivitas umum atau kepentingan hukum (Ryngaert, 2015).

Yurisdiksi merupakan kekuatan atau kewenangan negara untuk mengatur segala hal yang berada di dalam wilayah kedaulatannya.

Teori yurisdiksi juga merupakan dasar utama yang menjadi tumpuan negara-negara untuk melaksanakan kewenangannya seperti yang dinyatakan dalam resolusi-resolusi Dewan Keamanan PBB 1373 terhadap situasi terorisme maritim di wilayah perairan suatu negara.

b. Teori Pertanggungjawaban Negara

Menurut Hegel, pertanggung jawaban (schuld) merupakan pengejawantahan dari karakter kemanusiaan (bestimmung), atau secara singkat pertanggung jawaban ialah sisi kemanusiaan kita (Alznauer, 2015). Bagi Hegel, pertanggung jawaban dimaknai sebagai suatu yang normatif, sesuatu yang obyektif, dan pelaksanaannya hanya dilakukan bilamana dalam taraf ethical evaluation (evaluasi etik) tanpa harus bertanggung jawab secara spesifik apa yang benar (rechtlich) atau secara moral (moralisch). Selain itu, menurut Hegel, suatu pihak 
Jurnal Pembangunan Hukum Indonesia

Volume 2, Nomor 1, Tahun 2020
Program Studi Magister Ilmu Hukum Fakultas Hukum Universitas Diponegoro hanya dapat dimintai pertanggung-jawabannya hanya jika ia dianggap pantas untuk dimintai bertanggung jawab terhadap apa yang dia lakukan, sejauh dia mengetahui apa yang telah dilakukan, serta mengetahui apakah yang dilakukan itu baik atau buruk.

Dalam konteks negara, terdapat dua teori terkait bilamana negara melakukan perbuatan melawan hukum atau melakukan pembiaran terhadap suatu kesalahan atau niatan yang telah dilakukan pejabatnya, yang pertama ialah pertanggung jawaban mutlak atau pertanggung jawaban obyektif (disebut juga teori risiko) kemudian yang kedua ialah teori subyektif atau juga disebut teori kesalahan (Shaw, 2008). Teori pertanggungjawabanobyektif menyatakan bahwa sekali perbuatan melawan hukum terjadi yang menyebabkan kerugian yang mana dilakukan oleh aparat negara, maka negara tersebut akan bertanggung jawab dalam hukum internasional pada negara yang mengalami kerugian dengan itikad baik ataupun tidak, sedangkan teori tanggung jawab subyektif mengharuskan adanya elemen niatan (dolus) ataukah kelalaian (culpa) yang harus dibuktikan sebelum negara tersebut dimintai tanggung jawab atas kerugian yang ditimbulkan.

Sebelumnya ada beberapa penelitian yang mengangkat tema mengenai keamanan maritim dan terorisme maritim. Berbagai upaya telah dilakukan negara-negara untuk meningkatkan keselamatan dan keamanan navigasi, salah satunya adalah dengan membentuk Contingence Maritime Regime, dengan
Perangkat MDA. Substansi MDA (Maritime Domain Awareness) adalah terbangunnya pertukaran informasi, jaringan dan kegiatan analisis antara stakeholder maritim atas apa yang terjadi di laut dan sekitarnya sehingga dapat mendeteksi dan mengalahkan ancaman terorisme maritim (Santosa 2014).

Kemudian terdapat penelitian mengenai Terorisme Maritim dalam aspek politk internasional, regional, dan dalam negeri. Dalam menanggulangi Terorisme Maritim dibutuhkan sinergi antara pengaturan baik dalam lingkup nasional, regional, maupun internasional, karena kejahatan terorisme merupakan musuh umat manusia (Hostis Humanis Generis) (Djalal, 2004).

Apabila potensi ancaman keamanan maritim dari perompak, perampok laut dan potensi terorisme maritim di wilayah perairan negara pantai betul-betul terjadi, maka akan menambah keraguan negaranegara lain terhadap kemampuan negara pantai untuk mengamankan wilayahnya Kondisi tersebut akan memperkuat permintaan negara-negara besar atau user states untuk diberi hak yang serupa dengan negara pantai untuk menentukan keselamatan maritim di wilayah perairan negara pantai (Sagena, 2013).

Selain penelitian tersebut ada beberapa jurnal internasional yang mengangkat tema mengenai terorisme maritim yaitu belum adanya pengaturan internasional yang secara spesifik membahas permasalahan Terorisme Maritim (Hong \& Adolf, 2010). Kemudian terdapat penelitian yang berfokus 
Jurnal Pembangunan Hukum Indonesia

Volume 2, Nomor 1, Tahun 2020
Program Studi Magister IImu Hukum Fakultas Hukum Universitas Diponegoro pada pertanggungjawaban negara pantai apabila terjadi insiden terorisme maritim di wilayah kedaulatannya (Sittnick, 2005).

Pada penelitian dalam artikel ini menekankan pada Problematika hukum yang mungkin terjadi akibat kejahatan Terorisme Maritim terkait dengan pertanggungjawaban negara baik oleh negara pantai maupun negara bendera kapal. Titik fokus tersebut yang membedakan penelitian yang akan dilaksanakan oleh penulis dengan penelitianpenelitian sebelumnya. Tujuan dari penulisan ini yaitu untuk mengetahui dan menganalisis pertanggung jawaban baik negara pantai maupun negara bendera kapal terhadap insiden terorisme maritim.

Berdasarkan latar belakang tersebut, maka dapat dirumuskan rumusan permasalahan sebagai berikut;

1. Bagaimana Pertanggungjawaban negara pantai terkait Permasalahan Hukum yang timbul akibat terjadinya insiden Terorisme Maritim di wilayah teritorialnya?

2. Bagaimana pertanggungjawaban negara bendera kapal dalam insiden terorisme maritim yang menggunakan kapal?

\section{B. METODE PENELITIAN}

Metode pendekatan yang digunakan dalam artikel ini adalah pendekatan yuridis normatif, yaitu suatu pendekatan yang mengacu pada hukum dan peraturan perundang-undangan yang berlaku. Dalam penelitian ini digunakan spesifikasi penelitian secara deskriptif analitis. Deskriptif, yaitu penelitian yang bertujuan melukiskan tentang suatu hal di daerah tertentu dan pada saat tertentu.

Penelitian ini menggunakan sumber data kepustakaan. Jenis datanya adalah data sekunder yaitu data yang diperoleh melalui bahan pustaka dengan cara mengumpulkan dari berbagai sumber bacaan yang berhubungan dengan masalah yang diteliti. Analisis yang digunakan dalam penelitian ini menggunakan analisis kualitatif, yaitu menganalisis data yang berupa bahan-bahan hukum dan bahanbahan pustaka. Analisis dilakukan dengan penafsiran terhadap data hasil penelitian. Hasil analisis disajikan secara sederhana dan sistematis.

\section{HASIL DAN PEMBAHASAN}

\section{Terorisme Maritim sebagai ancaman terhadap kebebasan navigasi dalam yurisdiksi nasional dan tanggung jawab Negara Pantai}

Selalu ada kemungkinan dari serangan teroris terhadap kapal asing di dalam wilayah laut di bawah kedaulatan suatu Negara pantai. Akibatnya, muncul pertanyaan, apakah Negara pantai memiliki tanggung jawab untuk memastikan keamanan hak navigasi kapal-kapal asing di wilayah yurisdiksinya. Ada sejumlah permasalahan untuk menjawab pertanyaan ini. Pertama, apakah negara lain memiliki hak navigasi di dalam perairan di bawah yurisdiksi Negara pantai? Kedua, jika itu adalah hak, apakah Negara pesisir adalah penanggung jawab? Akhirnya, apakah kewajiban umum untuk mencegah terorisme dibebankan kepada Negara pantai untuk mengambil langkah-langkah proaktif untuk memastikan 
Jurnal Pembangunan Hukum Indonesia

Volume 2, Nomor 1, Tahun 2020
Program Studi Magister Ilmu Hukum Fakultas Hukum Universitas Diponegoro keamanan hak navigasi Negara-negara lain dalam yurisdiksinya?

Penting untuk menguraikan berbagai jenis hak navigasi yang dapat dinikmati oleh negara-negara asing di wilayah perairan dibawah yurisdiksi negara pantai. Negara asing memiliki hak lintas damai di dalam laut territorial. Hak ini diakui oleh hukum kebiasaan internasional dan dalam UNCLOS (Rothwell, 2009). Menurut UNCLOS, hak lintas damai diberikan selama tidak mengganggu perdamaian, ketertiban, atau keamanan negara pantai. Hak lintas damai juga harus dilakukan sesuai dengan UNCLOS dan aturan hukum internasional lainnya. Negara pantai memiliki wewenang untuk mengambil langkahlangkah yang diperlukan di wilayah laut teritorialnya untuk mencegah lintas yang tidak damai.

Dengan mempertimbangkan sejarah penyusunan UNCLOS, dapat disimpulkan bahwa memastikan keamanan hak navigasi adalah salah satu tujuan dari Konvensi, dan hal ini merupakan tugas dari negara pantai.

Dapat dikatakan bahwa ada kewajiban dalam hukum kebiasaan internasional untuk mencegah terorisme (Mellor, 2002). Baik Majelis Umum dan Dewan Keamanan PBB telah menekankan adanya upaya-upaya positif untuk mencegah terorisme. Menurut Resolusi Dewan Keamanan PBB 1373, Negara-negara anggota diharuskan untuk mengambil langkah-langkah yang diperlukan untuk mencegah tindakan terorsime. Resolusi ini mewajibkan negara pantai untuk mengambil semua langkah yang diperlukan untuk mencegah terorisme maritim di wilayah yurisdiksinya.

Kewajiban negara pantai secara spesifik diatur didalam Konvensi SUA. Konvensi SUA mewajibkan negara untuk mengambil segala langkah-langakah praktis untuk mencegah persiapan ataupun tindakan terorisme maritim di perairan teritorialnya, dimana ia memiliki kedaulatan territorial.

Masalah yang paling penting untuk ditentukan adalah apakah kelambanan suatu negara untuk mengambil langkah-langkah yang diperlukan untuk pencegahan terorisme maritim di laut territorial, perairan pedalaman, atau perairan kepulauannya merupakan pelanggaran terhadap kewajiban internasional. Kelalaian dapat menimbulkan kewajiban internasional. 'Tidak dilaksanakannya kewajiban internasional' dan 'tindakan yang tidak sesuai dengan kewajiban internasional', juga dapat dikatakan sebagai pelanggaran kewajiban internasional. Tidak mengambil langkah-langkah yang tepat untuk pencegahan terorisme maritim dan insiden teroris yang terjadi dalam wilayah hukum negara pantai dapat dianggap sebagai tidak dilaksanakannya kewajiban internasional dan lebih tepatnya dapat dikatakan sebagai tindakan yang tidak sesuai dengan kewajiban internasional.

Bagian ini dapat diringkas dengan mengatakan bahwa jika ada serangan teroris di perairan teritorial negara pantai, di mana negara gagal mengambil langkah-langkah yang tepat untuk memastikan keamanan di dalam perairannya, Negara bendera kapal yang diserang dapat meminta pertanggung 
Jurnal Pembangunan Hukum Indonesia

Volume 2, Nomor 1, Tahun 2020
Program Studi Magister IImu Hukum Fakultas Hukum Universitas Diponegoro jawaban Negara pantai secara internasional. Basis utama dari klaim ini adalah hak navigasi Negara Bendera dan pelanggaran konsekuensial atas hak tersebut. Lembaga peradilan internasional dapat memainkan peran penting dalam penyelesaian perselisihan yang timbul dari masalah ini. Namun, dalam hal ini tidak dapat diklaim bahwa, dalam setiap keadaan Negara pantai akan bertanggung jawab. la hanya mengklaim bahwa di mana Negara pantai secara lalai tidak mau memastikan keamanan kapal asing walaupun memiliki kapasitas, negara tersebut harus memikul beberapa bentuk tanggung jawab.

\section{Tanggung Jawab Negara Bendera dalam Terorisme Maritim dengan menggunakan \\ Kapal}

Sebuah kapal dapat digunakan untuk menyerang kapal lain, menyerang pelabuhan, dan instalasi lepas pantai. Dengan demikian, sangat penting untuk dibahas apakah negara bendera kapal tersebut memiliki tanggung jawab hukum atas tindakan terorisme, karena ada kekhawatiran bahwa teroris dapat memiliki dan mengoperasikan kapal menggunakan bendera kemudahan (Flag of Convenience) (Luft \& Anne, 2004). Praktek pemberian bendera tanpa pemeriksaan yang cermat menciptakan peluang yang menguntungkan bagi teroris untuk memiliki kapal yang dapat digunakan untuk serangan teroris. Ada bukti bahwa kelompokkelompok teroris seperti Al Qaeda dan Pembebasan Macan Tamil Eelam (LTTE) mengoperasikan kapal menggunakan bendera kemudahan, dan bahkan telah mengembangkan angkatan laut mereka sendiri (Murphy, 2008).

Dalam Hukum Internasional, pemilik kapal memiliki kebebasan penuh untuk memilih kewarganegaraan kapal mereka dan Negara memiliki hak untuk menetapkan peraturan dan standar sendiri untuk pendaftaran kapal dengan kewarganegaraan mereka, sesuai dengan hukum internasional yang berlaku. Ini berarti bahwa hanya negara bendera yang memiliki yurisdiksi atas kapal-kapalnya dilaut lepas.

Bendera Kemudahan biasanya mengacu pada negara-negara yang memungkinkan pendaftaran untuk pemilik kapal asing tanpa memiliki hubungan yang jelas dengan pemilik kapal. Banyak dari negaranegara yang membuka pendfataran kapal ini tidak memiliki kendali nyata atas kapal-kapal yang mengibarkan benderanya, yang dapat meningkatkan kemungkinan serangan teroris dengan menggunakan kapal-kapal tersebut (Marcopoulos, 2008). Praktik ini telah menciptakan tiga masalah khusus yaitu; kurangnya transparansi dalam kepemilikan kapal, kurangnya keamanan kapal, dan kurangnya kontrol terhadap kargo. Hal ini dapat mendorong teroris untuk dengan mudah memperoleh kapal dan mengibarkan bendera kemudahan suatu negara.

Penting untuk mengidentifikasi kapan tindakan terorisme yang menggunakan kapal dapat dikaitkan dengan bendera negara kapal yang digunakan dalam tindakan teroris. Sebagaimana dibahas sebelumnya, jika ada kelalaian dari pihak negara, negara dapat bertanggung jawab. Jika suatu negara tahu atau 
Jurnal Pembangunan Hukum Indonesia

Volume 2, Nomor 1, Tahun 2020
Program Studi Magister IImu Hukum Fakultas Hukum Universitas Diponegoro mengetahui secara pasti tentang bahanya, maka negara tersebut dianggap bertanggung jawab. Negara-negara yang memberikan bendera kepada pihak yang tidak diketahui harus sadar bahwa praktik ini dapat menciptakan masalah keamanan untuk negara lain (Murphy, 2008). Hal ini dapat dianggap sebagai penyalahgunaan hak dan menjalankan haknya tanpa itikad baik. UNCLOS dengan jelas memberlakukan kewajiban dengan itikad baik dan melarang penyalahgunaan hak.

Resolusi Dewan Kemanan PBB 1373 dapat menjadi sumber untuk tanggug jawab lebih lanjut dari negara bendera. Dewan keamanan memutuskan bahwa semua negara harus menahan diri dari memberikan segala bentuk dukungan baik aktif atau pasif, kepada entitas atau orang-orang yang terlibat dalam aksi-aksi terorisme.

Seperti dibahas sebelumnya bahwa kelompokkelompok teroris mengambil keuntungan dari adanya bendera kemudahan, kelalaian yang menyebabkan pemberian bendera dapat diartikan sebagai dukungan pasif kepada kelompok-kelompok teroris. Selain itu, menurut resolusi tersebut, negara-negara anggota diharuskan mengambil langkah-langkah yang diperlukan untuk mencegah aksi terorisme. Memberikan bendera kepada entitas yang mencurigakan tidak sesuai dengan kewajiban untuk mencegah aksi terorisme.

\section{SIMPULAN}

Negara pantai memiliki tanggung jawab jika sebuah kapal asing diserang oleh teroris di dalam perairannya di mana terdapat kelalaian serius di pihak Negara pantai dalam mengambil langkahlangkah yang tepat untuk memerangi terorisme maritim. Kemudian, suatu Negara juga akan bertanggung jawab jika mengganggu hak navigasi kapal asing. Namun, apakah suatu Negara akan bertanggung jawab atau tidak tergantung pada zona maritim di mana gangguan tersebut terjadi. Bab ini berpendapat bahwa Negara Bendera kapal mungkin juga bertanggung jawab jika kapalnya digunakan untuk serangan teroris terhadap kapal, pelabuhan, atau instalasi maritim negara lain ketika Negara Bendera telah menunjukkan keengganan dan kelalaian dalam membangun kontrol yang tepat atas kapal yang akan mengibarkan benderanya.

\section{DAFTAR PUSTAKA}

\section{BUKU}

Alznauer, M. (2015). Hegel's Theory of Responsibility. Cambridge: Cambridge University Press.

Ryngaert, C. (2015). J urisdiction in International Law (Second edition). Oxford: Oxford University Press

Shaw, M. (2008). International Law - Sixth Edition. Cambridge: Cambridge University Press.

Treves, T. (1990). Maritime Terrorism and International Law. Martinus Nijhoff Publishers.

\section{JURNAL}

Balkin, R. (2006). The International Maritime Organization and Maritime Security. Tulane Maritime Law J ournal, Vol 30, pp. 20. 
Jurnal Pembangunan Hukum Indonesia

Volume 2, Nomor 1, Tahun 2020
Program Studi Magister Ilmu Hukum Fakultas Hukum Universitas Diponegoro
Djalal, H. (2004). Terorisme di Laut: Aspek Politik Internasional- Regional dan Dalam Negeri. J urnal Ketahanan Nasional, Vol IX, (No.1), pp. 51.

Garmon, T. (2002). International Law of the Sea: reconciling the Law of Piracy and Terrorism in the Wake of September 11th.Tulane Maritime Law J ournal, Vol. 257, pp. 27.

Ho, J. (2006). The Security of Sea Lanes in Southeast Asia. J ournal Asian Survey, Vol 46, (No.4), pp 2.

Hong, Nong \& Adolf K Y. (2010). The International Legal Indtruments in addressing Piracy and Maritime Terrorism: A Critical Review. Research in Transportation Economics Journal Elsevier, Vol 27, pp. 51-60.

Luft, Gal. \& Korin, Anne. (2004). Terrorism Goes to Sea. J ournal Foreign Affairs, Vol.83, (No.61), pp. 70.

Marcopoulos, A. (2008). Flags of Terror: An Argument for Rethinking Maritime Security Policy Regarding Flags of Convenience. Tulane Maritime Law J ournal, Vol 32, pp. 294.

Mellor, J. (2002). Missing the Boat: The Legal and Practical Problems of the Prevention of Maritime Terrorism. American University International Law Review, Vol.341, (No.18), pp. 367.

Murphy, M. (2008). Small Boats, Weak States, Dirty, Money: Piracy and Maritime Terrorism in the Modern World. Maritime Safety and Security Law J ournal, Vol. 27,(No.7), pp. 347.
Rothwell, D. (2009). Innocent Passage in the Territoral Sea: The Unclos Regime and Asia Pacific State Practice. Yale Journal of International,Vol.34,Issue 2, pp.331-387

Sagena, W. (2013). Memahami Keamanan Tradisional dan Non-Tradisional di Selat Malaka Isu-isu dan Interaksi antar actor. J urnal Interdependence, Vol 1, (No. 1), pp. 1.

Sittnick, T. (2005). State Responsibility and Maritime Terrorism in the Strait of Malacca: Persuading Indonesia and Malaysia to Take Additional Steps to Secure the Strait. Pacific Rim Law and Policy J ournal, Vol 14, pp. 88.

Unii, N. (2006). Protecting the Straits of Malacca and Singapore against Piracy and Terrorism. International J ournal of Maritime and Coastal Law, Vol 21, pp. 12.

Wee, J. (2017). Maritime Terrorism Threat in Southeast Asia and its Challenges. J ournal of the Singapore Armed Forces, Vol 43, (No.2), pp 20.

Young, Adam J., \& Valencia, Mark J. (2003). Conflation of Piracy and Terrorism in Southeast Asia: Rectitude and Utility. Contemporary Southeast Asia : A Journal of International and Strategic Affair, Vol. 25, (No. 2) pp. 269.

\section{TESIS}

Santosa, G. (2014). Pembentukan Rezim Maritim untuk Mengatasi Ancaman Terorisme Maritim di Selat Malaka. Universitas Pertahanan. 